\title{
Economic Policy Uncertainty and Mutual Fund's Risk Adjusting Behavior in China
}

\author{
Zheming Li \\ School of Management, Jinan University, Guangzhou, China \\ Email: lzm9110@163.com
}

How to cite this paper: Li, Z. M. (2020). Economic Policy Uncertainty and Mutual Fund's Risk Adjusting Behavior in China. Modern Economy, 11, 609-619. https://doi.org/10.4236/me.2020.113045

Received: February 5, 2020

Accepted: March 8, 2020

Published: March 11, 2020

Copyright (C) 2020 by author(s) and Scientific Research Publishing Inc. This work is licensed under the Creative Commons Attribution International License (CC BY 4.0).

http://creativecommons.org/licenses/by/4.0/

\begin{abstract}
This paper investigates the effect of economic policy uncertainty on mutual fund's risk adjusting behavior by using the data of active management mutual funds operated in 2008-2017 in China. The empirical result shows a strong positive relationship between economic policy uncertainty and mutual fund's risk level. Moreover, mutual funds which performed better in the previous period are more eager to raise their risk levels when the uncertainty is high. It means that mutual funds may still take a risk to chase the limited money when the market sentiment is pessimistic. Our research contributes to the debate of the possible responses made by investors when market is in high uncertainty. It provides a reference for properly making policy decisions and accessing mutual funds.
\end{abstract}

\section{Keywords}

Economic Policy Uncertainty, Mutual Fund, Risk Adjusting

\section{Introduction}

Policy decision is the main way for government to realize macroeconomic regulation. Since the global financial crisis in 2008, governments all over the world made numerical policy decisions in the next several years trying to save the economy. On the one hand, these policy decisions generally produced positive impacts on economy and financial market in a short term. On the other hand, frequent policy changes also caused macroeconomic uncertainty. Therefore, the topic which is related to economic policy uncertainty has recently received high attention from academics. Especially, scholars tried to explain the responses made by corporations and investors when the market is in high uncertainty to investigate the potential damage caused by frequent policy changes.

Among all kinds of investors, mutual fund has gradually become one of the 
most influential institutional investors in Chinese financial market. According to Asset Management Association of China, there are 6544 mutual funds which are operating by the end of 2019. In general, numerous and differential products provide individual investors plenty choices. However, people also find it hard to distinguish the fund which rightly fits their preferences and prospects. Therefore, mutual funds' actions which show their investment style and risk preference attract more attention from both investors and scholars nowadays. To investigate mutual funds' risk adjustment is helpful for investors to pick up suitable products and for administrators to maintain a stable financial market especially when the macro environment is uncertainty.

Based on the above background, we contributed to the debate in this paper by investigating the effect of economic policy uncertainty on mutual fund's risk adjusting behavior in China. In this way, we get a deeper understanding about how uncertainty environment affects investors and financial market. Moreover, it provides more empirical evidence about mutual funds' risk adjustment behavior in different situations. Our results indicate that frequent policy change may cause mutual funds to be riskier since they need to gain limited money in financial market under uncertainty. It is also necessary to consider the macro factors such as economic policy uncertainty when assessing mutual funds' performance.

\section{Hypothesis Development}

Economy Policy Uncertainty, the unpredictability of changes on government's policy, has a great influence on the profitability and operation of corporations (Gulen \& Ion, 2015). The researches about EPU mainly include the following two aspects. One of them is to explore enterprises' financial behavior and operational decision such as investment behavior under high EPU environment ( $\mathrm{Pa}$ nousi \& Papanikolaou, 2012; Rao, Yue, \& Jiang, 2017). The other one is to investigate the potential influence that EPU brings to the return and volatility of all kinds of assets (Pástor \& Veronesi, 2013; Cui, Lin, \& Yao, 2018; Chen, Zhang, \& Zhao, 2018). Mutual fund, as an influential professional investor, is gradually becoming the focus of relative researches since its investment strategy is affected much by macro environment. Nowadays, scholars are mainly focusing on mutual funds' holdings and strategy under uncertainty. For example, mutual funds' demand for financial reporting quality and earning quality is increasing during political uncertainty events, which called flight to quality (Chen, Hope, Li, \& Wang, 2018; Peng, Xiao, \& Zhou, 2018). Moreover, in order to maintain the regular operation of mutual funds when facing the potential redemption under uncertainty, managers may sell stocks which are illiquid in the first place or hold more non-risky assets such as cash (Ben-Rephael, 2017; Li, Shi, \& Yang, 2015). These researches mainly consider that the raise of EPU increases the possibility that mutual funds fail to meet the expectation of investors, which causes managers' avoidance of risky assets. However, the nature of funds industry is more like a competition for cash flow (Brown, Harlow, \& Starks, 1996; Chevalier \& Ellison, 
1997). It is hard to keep the management scale just by avoiding investing risky assets under high uncertainty when investors generally raise their expectation of return since they take more risk by holding funds in that situation. Therefore, it's necessary to combine investors' requirement for return when discussing the possible behavior of mutual funds such as risk adjustment caused by EPU.

As a special macro factor, EPU mainly affect investor's preference for risky assets through ambiguity which refers to the unknown of probability that the expected return is reached. Investors generally prefer for the more certain return because of ambiguity aversion (Heath \& Tversky, 1991; Epstein \& Schneider, 2008). Brenner \& Izhakian (2018) found that ambiguity has a positive influence on expected return which is isolated from risk and changes with investors' expectation of the possibility that the return achieved. Investors only keep risky assets such as mutual fund when the return meets their requirement. Furthermore, scholars found that investors leave the financial market when EPU raises by calculating mutual funds' flow (Antoniou, Harris, \& Zhang, 2015; Tang, 2017). These researches above show that investors have stricter requirements for the return of risky assets or reduce the involvement of financial market. Therefore, managers of mutual funds may raise their portfolio risk level in order to chase a higher return performance to keep their product attractive. We suggest our first hypothesis based on the discussion above.

$\mathrm{H1}$ : Mutual funds raise the risk level when economic policy uncertainty increases.

Past return performance affects mutual fund's motivation to adjust risk level. Some researchers have shown that manager's motivation to adjust the risk level of portfolio is mainly affected by managerial incentives and employment risk (Kempf, Ruenzi, \& Thiele, 2009; Xiao, Peng, Xu, \& Wang, 2016). When EPU is high, investors prefer to hold assets with low risk and withdraw mutual funds. Under that situation, employment risk is dominant, which causes losers are more conservative in adjusting their risk level compared with winners. We suggest our third hypothesis based on the discussion above.

H2: Winners are more eager to raise the portfolio risk level when economic policy uncertainty increases.

\section{Variable and Model}

1) Intended Risk Adjustment

Relative researches which have been done before mainly used the volatility of return as a measurement of risk level. However, it's hard to show the real intention of adjusting the risk level of mutual fund's portfolio through this way. Therefore, Kempf, Ruenzi \& Thiele (2009) firstly introduced Intended Risk Adjustment calculated by using holding data instead of return data to measure the risk level adjustment. In this paper, we calculate this variable to express risk level adjustment. The detail procedures used by relative researches are shown as below (Kempf, Ruenzi, \& Thiele, 2009; Xiao, Peng, Xu, \& Wang, 2016; Wang, \& 
Jiang, 2013).

Firstly, we take half a year as a period and compute the intended risk level for the current period, $\sigma_{i, t}^{(2) \text { int }}$, based on the volatility of the monthly return in the last period of the portfolio which is held at the end of current period. Then, we compute the realized risk level for the past period, $\sigma_{i, t}^{(1)}$, based on the volatility of the monthly return that the fund realized in the last period. Finally, we calculate Intended Risk Adjustment Ratio (IRAR) based on the ratio of the intended risk level for the current period to he realized risk level for the past period. In the same way, we calculate Intended Risk Adjustment Level (IRAL) based on the difference between the intended risk level for the current period to he realized risk level for the past period.

$$
\begin{aligned}
& \operatorname{IRAR}_{i, t}=\sigma_{i, t}^{(2) \text { int }} / \sigma_{i, t}^{(1)} \\
& \operatorname{IRAL}_{i, t}=\sigma_{i, t}^{(2) \mathrm{int}}-\sigma_{i, t}^{(1)}
\end{aligned}
$$

Specifically, the portfolio of mutual fund includes stock, cash and government bond. We compute the return data by adding the return of these two parts which are calculated respectively. The return of cash and government bond is calculated based on the monthly risk-free return represented by three-month Shanghai Interbank Offered Rate.

2) Economic Policy Uncertainty

In this paper, we use EPU index firstly introduced by Bloom, Baker and Davis to measure the economic policy uncertainty of China (Baker, Bloom, \& Davis, 2016). They construct a scaled frequency count of articles about policy-related economic uncertainty in the South China Morning Post (SCMP), Hong Kong's leading English-language newspaper. We use the logarithm of the average monthly EPU of the current period to represent the economic policy uncertainty level of Chinese market.

\section{3) Control Variable}

We choose variables which are related to fund characteristic and investment style to control the potential influence in our regression. The control variable about fund characteristic includes fund size, fund age, fund expense ratio, fund position and institutional investor ratio. The control variable about investment style includes size style, value style, momentum style and volatility style. The detail definition and construction of these variables are shown in Table 1.

4) Model Design

In this paper, we analyze the panel data by using a multivariate regression framework. Specifically, we estimate the following regression model.

$$
\begin{aligned}
\text { IRA }_{i, t}= & \alpha_{i, t}+\beta_{1} \text { LnEPU }_{t-1}+\beta_{2} \text { LnTNA }_{i, t}+\beta_{3} \text { LnAge }_{i, t} \\
& +\beta_{4} \text { Expense }_{i, t-1}+\beta_{5} \text { Holding }_{i, t-1}+\beta_{6} \text { Insholder }_{i, t-1} \\
& +\beta_{7} \text { Stgy_size }_{i, t-1}+\beta_{8} \text { Stgy_bm }_{i, t-1}+\beta_{9} \text { Stgy_mom }_{i, t-1} \\
& +\beta_{10} \text { Stgy_vol }+\varepsilon_{i, t}
\end{aligned}
$$

where the dependent variable is Intended Risk Adjustment which is represented 
Table 1. Variable definitions.

\begin{tabular}{|c|c|}
\hline Variables & Definitions \\
\hline IRAR & Intended Risk Adjustment Ratio, $\operatorname{IRAR}_{i, t}=\sigma_{i, t}^{(2) \text { int }} / \sigma_{i, t}^{(1)}$ \\
\hline IRAL & Intended Risk Adjustment Level, IRAL $_{i, t}=\sigma_{i, t}^{(2) \text { int }}-\sigma_{i, t}^{(1)}$ \\
\hline LnEPU & The logarithm of the average monthly EPU \\
\hline LnTNA & The logarithm of the average fund net asset \\
\hline LnAge & The logarithm of the fund month age at the beginning of the period \\
\hline Expense & The ratio of the fund management fee to fund net asset \\
\hline Holding & The ratio of stock to fund net asset \\
\hline InsHolder & The ratio of institutional investor \\
\hline Stgy_size & The weighted average of the quantile of stock market value at the fund level \\
\hline Stgy_bm & The weighted average of the quantile of stock book-to-market ratio at the fund level \\
\hline Stgy_mom & The weighted average of the quantile of stock return at the fund level \\
\hline Stgy_vol & The weighted average of the quantile of stock volatility at the fund level \\
\hline
\end{tabular}

by Intended Risk Adjustment Ratio and Intended Risk Adjustment Level. The independent variable we use is the logarithm of the average monthly EPU of previous period since there it takes time to response to the change of EPU. For the same reason, we also use the data of previous period to represent the control variables except fund size. Furthermore, we use the fixed effect regression and control the time effect according to the result of Hausman test.

\section{Sample and Data}

1) Sample Selection

We collect the data of the mutual funds which operated in 2008-2017 in China as the research sample. Furthermore, we filter the original sample by the following steps. First of all, we remove all the passive management funds from the original sample since this kind of fund is often designed to track one particular index with a stable investment plan. Then, we remove the funds operated less than 1 year at the beginning of the period. That is because newly issued mutual funds in Chinese market usually need less than 3 months to build their portfolio. Therefore, funds operated more than 1 year should be more representative in risk adjustment actions. In the next step, funds that stopped operation during the sample period are removed from the sample since continuous data are required. Finally, we remove the funds with incomplete data that can't be supplemented through our manual collection and get our sample that consists of 5560 observations in 20 cross sections. In this paper, mutual fund data including basic operation information, financial report, return performance and market return are obtained from Resset Financial Database (http://www.resset.cn/). The Chinese Economic Policy Uncertainty Index is obtained from http://www.policyuncertainty.com/china_monthly.html. 
2) Summary Statistics

The summary statistics of main variables are shown in fic2 in Table 2. Firstly, the mean value and median value of IRAR and IRAL show that mutual funds generally keep a balanced risk level in sample period. Moreover, we can learn that the mean value and median value of the position of mutual fund is above $80 \%$. It means that the mutual funds we selected fit the regulation towards the position of active management fund in China. Furthermore, we can learn that mutual funds prefer large-cap style, growth style and low-volatility style portfolio by checking the summary statistics of control variables about investment style.

\section{Regression Analysis}

1) EPU and the Intended Risk Adjustment of Mutual Funds

Table 3 is the result of investigating how EPU affects the intended risk adjustment of mutual funds by using a multivariate regression. The results reported in Table 3 show a positive and statistically significant relation between EPU and intended risk adjustment of mutual funds. This finding supports our first hypothesis that mutual funds raise the risk level when economic policy uncertainty increases. Meanwhile, by checking the regression coefficient that explains fund characteristic and investment style, we can learn that large-size funds and the funds with large position are more eager to reduce the risk level. However, funds owned more by institutional investors or that require expensive expense are more eager to raise the risk level. These two findings are consistent with the theory that mutual funds need to maintain a balanced risk level by reducing their risk level when they exposed to high risk in the last period. But they are willing to chase for keeping their product attractive by raising risk level if its position of mutual fund is above $80 \%$.

Table 2. Summary statistics.

\begin{tabular}{ccccccc}
\hline Variables & P1 & P50 & P99 & Mean & Sd & N \\
\hline IRAR & 0.326 & 0.939 & 2.315 & 0.985 & 0.365 & 5560 \\
IRAL & -0.079 & -0.003 & 0.047 & -0.005 & 0.022 & 5560 \\
LnEPU & 4.543 & 5.070 & 6.144 & 5.235 & 0.554 & 5560 \\
LnTNA & 17.59 & 21.25 & 23.54 & 21.00 & 1.435 & 5560 \\
LnAge & 2.639 & 4.111 & 5.075 & 4.030 & 0.608 & 5560 \\
Expense & 0.001 & 0.008 & 0.019 & 0.008 & 0.003 & 5560 \\
Holding & 0.539 & 0.853 & 0.950 & 0.829 & 0.100 & 5560 \\
InsHolder & 0.000 & 0.093 & 0.873 & 0.178 & 0.209 & 5560 \\
Stgy_size & 3.265 & 6.851 & 8.970 & 6.734 & 1.284 & 5560 \\
Stgy_bm & 1.326 & 3.769 & 7.364 & 3.858 & 1.307 & 5560 \\
Stgy_mom & 2.255 & 5.470 & 8.315 & 5.448 & 1.347 & 5560 \\
Stgy_vol & 1.363 & 3.890 & 7.130 & 3.985 & 1.274 & 5560 \\
\hline
\end{tabular}


Table 3. Economic policy uncertainty and intended risk adjustment.

\begin{tabular}{|c|c|c|c|c|c|c|}
\hline \multirow[t]{2}{*}{ Variables } & \multicolumn{3}{|c|}{ IRAR } & \multicolumn{3}{|c|}{ IRAL } \\
\hline & (1) & (2) & (3) & $(4)$ & (5) & (6) \\
\hline \multirow[t]{2}{*}{$\operatorname{LnEPU}_{t-1}$} & $0.061^{\star * *}$ & $0.093^{* * *}$ & $0.222^{* * *}$ & $0.011^{* * *}$ & $0.012^{* * *}$ & $0.017^{\star * *}$ \\
\hline & $(4.47)$ & $(2.86)$ & $(6.17)$ & $(9.59)$ & $(5.69)$ & $(7.35)$ \\
\hline \multirow[t]{2}{*}{ LnTNA } & & $-0.020^{\star *}$ & $-0.019^{* *}$ & & $-0.001^{*}$ & $-0.001^{\star}$ \\
\hline & & $(-2.06)$ & $(-1.97)$ & & $(-1.91)$ & $(-1.70)$ \\
\hline \multirow[t]{2}{*}{ LnAge } & & $-0.045^{\star \star}$ & $-0.050^{\star *}$ & & -0.002 & $-0.003^{\star}$ \\
\hline & & $(-2.00)$ & $(-2.18)$ & & $(-1.57)$ & $(-1.89)$ \\
\hline \multirow[t]{2}{*}{ Expense $_{t-1}$} & & $5.153^{* *}$ & $4.664^{* \star}$ & & $0.482^{* * *}$ & $0.438^{\star * *}$ \\
\hline & & $(2.33)$ & $(2.10)$ & & $(3.15)$ & $(2.83)$ \\
\hline \multirow[t]{2}{*}{ Holding $_{t-1}$} & & $-0.296^{* * *}$ & $-0.202^{\star}$ & & $-0.024^{\star * *}$ & $-0.021^{\star * *}$ \\
\hline & & $(-4.80)$ & $(-1.89)$ & & $(-6.20)$ & $(-3.28)$ \\
\hline \multirow[t]{2}{*}{ Insholder $_{t-1}$} & & $0.075^{* *}$ & $0.073^{* *}$ & & $0.007^{* * *}$ & $0.006^{\star * *}$ \\
\hline & & $(2.56)$ & $(2.45)$ & & $(3.23)$ & $(3.06)$ \\
\hline \multirow[t]{2}{*}{ Stgy_size $_{t-1}$} & & & $0.015^{\star *}$ & & & $0.002^{\star * *}$ \\
\hline & & & (1.99) & & & $(3.06)$ \\
\hline \multirow[t]{2}{*}{ Stgy_bm ${ }_{t-1}$} & & & -0.007 & & & 0.000 \\
\hline & & & $(-1.11)$ & & & $(0.21)$ \\
\hline \multirow[t]{2}{*}{ Stgy_mom $_{t-1}$} & & & 0.001 & & & 0.000 \\
\hline & & & $(0.18)$ & & & $(0.54)$ \\
\hline \multirow[t]{2}{*}{ Stgy_vol ${ }_{t-1}$} & & & $-0.028^{* * *}$ & & & $-0.002^{\star * *}$ \\
\hline & & & $(-4.01)$ & & & $(-5.62)$ \\
\hline \multirow[t]{2}{*}{ Cons } & $0.528^{\star * *}$ & $1.151^{\star * *}$ & $0.491^{*}$ & $-0.073^{\star * *}$ & -0.027 & $-0.057^{\star * *}$ \\
\hline & $(6.90)$ & $(4.22)$ & (1.75) & $(-10.36)$ & $(-1.42)$ & $(-2.99)$ \\
\hline Time effect & Control & Control & Control & Control & Control & Control \\
\hline Fixed effect & Control & Control & Control & Control & Control & Control \\
\hline $\mathrm{N}$ & 5560 & 5560 & 5560 & 5560 & 5560 & 5560 \\
\hline$R^{2}$ & 0.213 & 0.220 & 0.225 & 0.279 & 0.290 & 0.301 \\
\hline
\end{tabular}

a. The numbers in parentheses are the $\mathrm{T}$ values obtained by cluster adjustment of the company. ${ }^{* *}$ indicates a significance level of $0.01,{ }^{* *}$ indicates a significance level of 0.05 , and ${ }^{*}$ indicates a significance level of 0.1 .

\section{2) Fund Performance and Risk Adjustment}

In this part, we examine whether performance in previous period affects fund risk adjustment under uncertainty. Firstly, we divided funds into two groups according to the performance in previous period. We tagged the funds which performed better than half of the funds operated in the same period as "Winner". Accordingly, those funds which underperformed are called "loser". For convenience, we use a dummy variable, D_ret, to indicate whether the fund is winner or 
not. D_ret equals 1 when the fund is winner and it equals 0 when the fund is loser. Specifically, we estimate the following regression model.

$\mathrm{IRA}_{i, t}=\alpha_{i, t}+\beta_{1} \operatorname{LnEPU}_{t-1}+\beta_{2} \mathrm{D} \_$ret $\times \mathrm{LnEPU}_{t-1}+\beta_{3} \mathrm{D} \_$ret $+\sum$ Controls $+\varepsilon_{i, t}(4)$

Table 4 is the result of examining how fund performance affects the risk adjustment of mutual funds under EPU by using a multivariate regression. We can

Table 4. Fund performance and intended risk adjustment in uncertainty.

\begin{tabular}{|c|c|c|c|c|c|c|}
\hline \multirow[t]{2}{*}{ Variables } & \multicolumn{3}{|c|}{ IRAR } & \multicolumn{3}{|c|}{ IRAL } \\
\hline & (1) & (2) & (3) & $(4)$ & (5) & (6) \\
\hline \multirow{2}{*}{$\operatorname{LnEPU}_{t-1}$} & $0.030^{*}$ & $0.057^{*}$ & $0.188^{* * *}$ & $0.009^{* * *}$ & $0.010^{* * *}$ & $0.015^{\star * *}$ \\
\hline & (1.79) & $(1.70)$ & $(5.06)$ & $(7.21)$ & $(4.37)$ & $(6.20)$ \\
\hline \multirow[t]{2}{*}{ D_ret $\times$ LnEPU $_{t-1}$} & $0.063^{* * *}$ & $0.067^{* * *}$ & $0.062^{\star * *}$ & $0.004^{* * *}$ & $0.004^{* * *}$ & $0.004^{* * *}$ \\
\hline & $(3.88)$ & $(4.11)$ & $(3.80)$ & $(4.78)$ & $(5.02)$ & $(4.36)$ \\
\hline \multirow[t]{2}{*}{ D_ret } & $-0.328^{\star * *}$ & $-0.338^{\star \star \star}$ & $-0.315^{\star \star \star}$ & $-0.021^{\star \star \star}$ & $-0.021^{* * *}$ & $-0.019^{\star * *}$ \\
\hline & $(-3.81)$ & $(-3.93)$ & $(-3.66)$ & $(-4.52)$ & $(-4.61)$ & $(-4.02)$ \\
\hline \multirow[t]{2}{*}{ LnTNA } & & $-0.023^{\star *}$ & $-0.022^{* *}$ & & $-0.001^{\star *}$ & $-0.001^{*}$ \\
\hline & & $(-2.30)$ & $(-2.18)$ & & $(-2.16)$ & $(-1.92)$ \\
\hline \multirow[t]{2}{*}{ LnAge } & & $-0.046^{* *}$ & $-0.051^{* *}$ & & -0.002 & $-0.003^{\star}$ \\
\hline & & $(-2.01)$ & $(-2.21)$ & & $(-1.53)$ & $(-1.88)$ \\
\hline \multirow[t]{2}{*}{ Expense $_{t-1}$} & & $5.884^{* *}$ & $5.108^{* *}$ & & $0.569^{* * *}$ & $0.496^{* * *}$ \\
\hline & & $(2.49)$ & $(2.17)$ & & $(3.53)$ & $(3.08)$ \\
\hline \multirow[t]{2}{*}{ Holding $_{t-1}$} & & $-0.295^{\star * *}$ & $-0.190^{*}$ & & $-0.024^{* * *}$ & $-0.020^{\star * *}$ \\
\hline & & $(-4.79)$ & $(-1.77)$ & & $(-6.17)$ & $(-3.15)$ \\
\hline \multirow[t]{2}{*}{ Insholder $_{t-1}$} & & $0.073^{* \star}$ & $0.071^{\star *}$ & & $0.006^{* * *}$ & $0.006^{* * *}$ \\
\hline & & $(2.49)$ & $(2.40)$ & & $(3.13)$ & $(2.99)$ \\
\hline \multirow[t]{2}{*}{ Stgy_size ${ }_{t-1}$} & & & $0.013^{*}$ & & & $0.001^{\star \star \star}$ \\
\hline & & & (1.79) & & & $(2.92)$ \\
\hline \multirow[t]{2}{*}{ Stgy_bm ${ }_{t-1}$} & & & -0.007 & & & 0.000 \\
\hline & & & $(-1.10)$ & & & $(0.24)$ \\
\hline \multirow[t]{2}{*}{ Stgy_mom $t_{t-1}$} & & & -0.001 & & & 0.000 \\
\hline & & & $(-0.08)$ & & & $(0.02)$ \\
\hline \multirow[t]{2}{*}{ Stgy_vol $_{t-1}$} & & & $-0.026^{* * *}$ & & & $-0.002^{* * *}$ \\
\hline & & & $(-3.69)$ & & & $(-5.21)$ \\
\hline \multirow[t]{2}{*}{ Cons } & $0.690^{* * *}$ & $1.384^{* * *}$ & $0.715^{\star *}$ & $-0.062^{\star * *}$ & -0.011 & $-0.043^{\star *}$ \\
\hline & $(7.62)$ & $(4.89)$ & $(2.46)$ & $(-8.31)$ & $(-0.58)$ & $(-2.18)$ \\
\hline Time effect & Control & Control & Control & Control & Control & Control \\
\hline Fixed effect & Control & Control & Control & Control & Control & Control \\
\hline $\mathrm{N}$ & 5560 & 5560 & 5560 & 5560 & 5560 & 5560 \\
\hline$R^{2}$ & 0.216 & 0.223 & 0.227 & 0.282 & 0.294 & 0.304 \\
\hline
\end{tabular}

a. The numbers in parentheses are the $\mathrm{T}$ values obtained by cluster adjustment of the company. ${ }^{* *}$ indicates a significance level of $0.01,{ }^{*}$ indicates a significance level of 0.05 , and ${ }^{*}$ indicates a significance level of 0.1 . 
find that there is a positive and statistically significant relation between intersection D_ret $\times \operatorname{LnEPU}_{t-1}$ and risk adjustment of mutual funds. It supports the hypothesis 3 that Winners are more eager to raise the portfolio risk level when economic policy uncertainty increases.

3) Robustness Analysis

In this paper, we use the monthly EPU index data to measure the economic policy uncertainty of Chinese market. However, the average value of EPU in a long period may weaken the influence of uncertainty in recent time. Therefore, we calculate a weighted average of the uncertainty developed by scholars, using a weight of one-sixth for the first two months, one-third for the next two months, and one-half for the last two months (Gulen, \& Ion, 2015; Rao, Yue, \& Jiang, 2017; Tang, 2017). Furthermore, we use the EPU index of the current period to measure the uncertainty since the risk adjustment may happen at any time.

The result of Table 5 shows that mutual funds prefer raising the risk level when EPU improves, which is consistent with the hypothesis and main conclusion in the main part of our paper.

Table 5. Robustness analysis.

\begin{tabular}{|c|c|c|c|c|c|c|}
\hline \multirow[t]{2}{*}{ Variables } & \multicolumn{3}{|c|}{ IRAR } & \multicolumn{3}{|c|}{ IRAL } \\
\hline & (1) & (2) & (3) & (4) & (5) & (6) \\
\hline \multicolumn{7}{|c|}{ Panel A: Using the weighted average EPU index } \\
\hline \multirow[t]{2}{*}{ LnAdjEPU $_{t-1}$} & $0.162^{\star * *}$ & $0.098^{* * *}$ & $0.215^{\star * *}$ & $0.014^{* * *}$ & $0.013^{\star * *}$ & $0.017^{\star * *}$ \\
\hline & (10.66) & $(2.86)$ & $(6.17)$ & (11.91) & (5.69) & $(7.35)$ \\
\hline Fund characteristic & & Control & Control & & Control & Control \\
\hline Investment style & & & Control & & & Control \\
\hline \multirow[t]{2}{*}{ Cons } & 0.065 & $1.128^{* * *}$ & $0.518^{*}$ & $-0.086^{* * *}$ & -0.030 & $-0.055^{\star * *}$ \\
\hline & $(0.78)$ & $(4.06)$ & $(1.86)$ & $(-12.13)$ & $(-1.55)$ & $(-2.91)$ \\
\hline Time effect & Control & Control & Control & Control & Control & Control \\
\hline Fixed effect & Control & Control & Control & Control & Control & Control \\
\hline $\mathrm{N}$ & 5560 & 5560 & 5560 & 5560 & 5560 & 5560 \\
\hline$R^{2}$ & 0.213 & 0.220 & 0.225 & 0.279 & 0.290 & 0.301 \\
\hline \multicolumn{7}{|c|}{ Panel B: Using EPU index of the current period } \\
\hline \multirow[t]{2}{*}{$\mathrm{LnEPU}_{t}$} & $0.217^{\star * *}$ & $0.251^{* * *}$ & $0.289^{* * *}$ & $0.019^{* * *}$ & $0.020^{* * *}$ & $0.022^{\star * *}$ \\
\hline & $(10.66)$ & $(5.83)$ & $(6.17)$ & $(11.91)$ & $(6.93)$ & $(7.35)$ \\
\hline Fund characteristic & & Control & Control & & Control & Control \\
\hline Investment style & & & Control & & & Control \\
\hline \multirow[t]{2}{*}{ Cons } & $-0.277^{\star *}$ & 0.324 & 0.0640 & $-0.116^{* * *}$ & $-0.069^{* * *}$ & $-0.090^{* * *}$ \\
\hline & $(-2.42)$ & $(1.02)$ & $(0.19)$ & $(-12.08)$ & $(-3.14)$ & $(-4.06)$ \\
\hline Time effect & Control & Control & Control & Control & Control & Control \\
\hline Fixed effect & Control & Control & Control & Control & Control & Control \\
\hline $\mathrm{N}$ & 5560 & 5560 & 5560 & 5560 & 5560 & 5560 \\
\hline$R^{2}$ & 0.213 & 0.220 & 0.225 & 0.279 & 0.290 & 0.301 \\
\hline
\end{tabular}

a. The numbers in parentheses are the $\mathrm{T}$ values obtained by cluster adjustment of the company. ${ }^{* *}$ indicates a significance level of $0.01,{ }^{* *}$ indicates a significance level of 0.05 , and ${ }^{*}$ indicates a significance level of 0.1 . 


\section{Conclusion}

In this study, we analyze the effect of economic policy uncertainty on the risk adjustment of mutual funds, paying close attention to the actions of institutional investors under macro environment's changing. To capture the overall level of economic policy uncertainty of China, we employ a measure developed by Baker, Bloom, \& Davis (2013), which is based in large part on frequency counts of key terms in newspaper articles. Using this measure, we document a strong positive relationship between economic policy uncertainty and mutual funds' raising risk level which is more significant on the funds performed better in the previous period. This result is robust to controlling for fund characteristics, investment styles and alternative measures of macroeconomic uncertainty.

Our results have some main implications. First, they suggest that when making policy decisions, regulators should be mindful of the fact that the uncertainty environment caused by policy decisions can be just as damaging as making the wrong decision. As an influential investor in financial market, mutual funds may become riskier to chase the limited money when uncertainty increases, which may cause severe fluctuation of financial market. Second, our results indicate that in assessing mutual funds, we should be aware of their own motivation to adjust the investment style, especially when the market is in high uncertainty.

\section{Conflicts of Interest}

The authors declare no conflicts of interest regarding the publication of this paper.

\section{References}

Antoniou, C., Harris, R. D. F., \& Zhang, R. (2015). Ambiguity Aversion and Stock Market Participation: An Empirical Analysis. Journal of Banking \& Finance, 58, 57-70. https://doi.org/10.1016/j.jbankfin.2015.04.009

Baker, S. R., Bloom, N., \& Davis, S. J. (2016). Measuring Economic Policy Uncertainty. The Quarterly Journal of Economics, 131, 1593-1636. https://doi.org/10.1093/qje/qjw024

Brenner, M., \& Izhakian, Y. (2018). Asset Pricing and Ambiguity: Empirical Evidence. Journal of Financial Economics, 130, 503-531. https://doi.org/10.1016/j.jfineco.2018.07.007

Brown, K. C., Harlow, W. V., \& Starks, L. T. (1996). Of Tournaments and Temptations: An Analysis of Managerial Incentives in the Mutual Fund Industry. The Journal of Finance, 51, 85-110. https://doi.org/10.1111/j.1540-6261.1996.tb05203.x

Chen, F., Hope, O.K., Li, Q., \& Wang, X. (2018). Flight to Quality in International Markets: Investors' Demand for Financial Reporting Quality during Political Uncertainty Events. Contemporary Accounting Research, 35, 117-155. https://doi.org/10.1111/1911-3846.12355

Chen, G. J., Zhang, R. Z., \& Zhao, X. Q. (2018). Economic Policy Uncertainty and Stock Risk Characteristics. Journal of Management Sciences in China, 21, 1-27.

Chevalier, J., \& Ellison, G. (1997). Risk Taking by Mutual Funds as a Response to Incentives. Journal of Political Economy, 105, 1167-1200. https://doi.org/10.1086/516389 
Cui, X., Lin, Y., \& Yao, S. Y. (2018). Exposure to "Economic Policy Uncertainty" and Risk of Plunging Stock Prices. Financial Economics Research, 33, 98-108.

Epstein, L. G., \& Schneider, M. (2008). Ambiguity, Information Quality, and Asset Pricing. The Journal of Finance, 63, 197-228. https://doi.org/10.1111/j.1540-6261.2008.01314.x

Gulen, H., \& Ion, M. (2015). Policy Uncertainty and Corporate Investment. The Review of Financial Studies, 29, 523-564. https://doi.org/10.1093/rfs/hhv050

Heath, C., \& Tversky, A. (1991). Preference and Belief: Ambiguity and Competence in Choice under Uncertainty. Journal of Risk \& Uncertainty, 4, 5-28. https://doi.org/10.1007/BF00057884

Kempf, A., Ruenzi, S., \& Thiele, T. (2009). Employment Risk, Compensation Incentives, and Managerial Risk Taking: Evidence from the Mutual Fund Industry. Journal of Financial Economics, 92, 92-108. https://doi.org/10.1016/j.jfineco.2008.05.001

Li, F. Y., Shi, Y. D., \& Yang, M. Z. (2015). Does Economic Policy Uncertainty Affect Mutual Fund Investment? Research Based on Chinese Economic Policy Uncertainty Index. Securities Market Herald, No. 5, 52-59.

Panousi, V., \& Papanikolaou, D. (2012). Investment, Idiosyncratic Risk, and Ownership. The Journal of Finance, 67, 1113-1148. https://doi.org/10.1111/j.1540-6261.2012.01743.x

Pástor, L., \& Veronesi, P. (2013). Political Uncertainty and Risk Premia. Journal of Financial Economics, 110, 520-545. https://doi.org/10.1016/j.jfineco.2013.08.007

Peng, W. P., Xiao, J. H., \& Zhou, Y. J. (2018). Market Conditions and the Fund Behavior of Flight to Quality: A Study Based on Earnings Quality. Journal of Finance and Economics, 44, 4-17.

Ben-Rephael, A. (2017). Flight-to-Liquidity, Market Uncertainty, and the Actions of Mutual Fund Investors. Journal of Financial Intermediation, 31, 30-44. https://doi.org/10.1016/j.jfi.2017.05.002

Rao, P. G., Yue, H., \& Jiang, G. H. (2017). Economic Policy Uncertainty and Firms' Investment. The Journal of World Economy, No. 2, 27-51.

Tang, C. (2017). Economic Policy Uncertainty and Financial Market Participation: An Empirical Analysis Based on Mutual Fund Flow. Review of Investment Studies, 36, 76-93.

Wang, Y. M., \& Jiang, Y. B. (2013). Research on Influence of Compensation Incentive, Employment Risk and Deviation from the Expect upon Open-End Fund Risk Shifting Behavior in China. Management Review, 25, 12-22.

Xiao, J. H., Peng, W. P., Xu, J., \& Wang, Q. (2016). Performance Ranking and Intended Risk Adjustment: New Evidences of Interactive Effect between Compensation Incentive and Employment Risk. China Economic Quarterly, 15, 1177-1204. 